\title{
MODEL PREDATOR-PREY DENGAN DUA PREDATOR
}

\author{
Danar Agus Nugroho dan Rina Reorita \\ Prodi Matematika, Fakultas Sains dan Teknik Universitas Jenderal Soedirman \\ Email : vorker_portrait23@yahoo.com reo.rina@yahoo.com
}

\begin{abstract}
This paper discussed about the predator-prey model with two predators. This model is a development of the model given by Korobeinikov and Wake (1999). Dynamic behavior of the model can be determined based on the stability of the equilibrium point. The stability of the equilibrium point of predator-prey model with two predators on the general ecosystem shows that there is no coexistence state (grown in tandem) on both predators and for a long time one of the predators will lead to the local extinction even though there is no competition between the two predators. Furthermore, this model is applied to the brown plant hopper predator, mirid prey and tomcat prey. The result shows that the population of brown planthopper and both of the predators will oscillate towards a particular value with a shorter span of time. In the long term, the number of brown planthopper and mirid will be heading to the equilibrium point, while the tomcat will lead to local extinction.
\end{abstract}

Keywords: predation, predator-prey model with two predators, stability of equilibrium points.

ABSTRAK. Pada makalah ini dibahas mengenai model predator-prey dengan dua predator. Model ini merupakan pengembangan dari model yang diberikan oleh Korobeinikov dan Wake (1999). Perilaku dinamik model dapat diketahui dengan menentukan kestabilan titik kesetimbangan. Kestabilan titik kesetimbangan model predator-prey dengan dua predator pada ekosistem secara umum tidak menunjukkan terjadinya keadaan koeksistensi (tumbuh secara beriringan) pada kedua predator dan untuk jangka waktu yang lama salah satu predator akan mengarah pada kepunahan lokal meskipun tidak ada kompetisi di antara kedua predator. Selanjutnya, model ini diaplikasikan pada predator wereng batang coklat, dan prey kepik mirid serta kumbang tomcat. Hasilnya menunjukkan bahwa jumlah populasi wereng batang coklat dan kedua predator tersebut akan berosilasi menuju nilai tertentu dengan rentang waktu yang semakin singkat. Dalam jangka waktu yang lama, jumlah wereng batang coklat dan kepik mirid akan menuju ke nilai tertentu, sedangkan kumbang tomcat akan mengarah pada kepunahan lokal.

Kata kunci: predasi, model predator-prey dengan dua predator, kestabilan titik kesetimbangan. 


\section{PENDAHULUAN}

Salah satu bentuk interaksi yang terjadi di dalam ekosistem adalah predasi, yaitu hubungan antara predator (pemangsa) dan prey (mangsa) (Campbell dan Reece, 2004). Hubungan antara predator dan prey dapat dimodelkan secara matematis menjadi model predator-prey. Menurut Edwards dan Penney (2008), model predator-prey yang paling sederhana adalah model Lotka-Volterra dengan asumsi pertumbuhan prey mengikuti pertumbuhan Malthus. Akan tetapi, model tersebut memiliki kelemahan karena pada model pertumbuhan Malthus, populasi tumbuh secara tidak terbatas seiring dengan pertambahan waktu. Pada kenyataannya, suatu populasi tidak dapat bertambah secara terus menerus karena adanya faktor-faktor penghambat pertumbuhan populasi seperti ruang hidup, makanan, maupun lingkungan. Berdasarkan hal tersebut, model Lotka-Volterra kemudian dimodifikasi dengan mengasumsikan pertumbuhan prey mengikuti pertumbuhan logistik.

Model Lotka-Volterra hanya melibatkan satu predator dan satu prey saja sedangkan pada beberapa ekosistem terdapat predasi yang melibatkan dua predator dengan prey yang sama. Contoh predasi semacam ini adalah wereng batang coklat (Nilaparvata lugens Stal.) yang dimangsa oleh predator alaminya, seperti kepik mirid (Cyrtorhinus lividipennis Reuter.) dan kumbang tomcat (Paederus fuscifes Curt.) (Laba, 2001). Model Lotka-Volterra dapat dikembangkan untuk memodelkan interaksi antara dua predator dan satu prey. Korobeinikov dan Wake (1999), telah menurunkan model dua predator dan satu prey ke dalam sistem persamaan diferensial. Dengan menganalisa kestabilan pada titik kesetimbangan, dapat diketahui bahwa tidak ada koeksistensi kedua predator pada ekosistem. Koeksistensi kedua predator terjadi pada kasus patologis saja.

Artikel ini mengkaji model yang merupakan pengembangan model yang ditulis oleh Korobeinikov dan Wake (1999). Model dua predator dan satu prey yang dibahas oleh Korobeinikov dan Wake (1999) menggunakan asumsi pertumbuhan prey mengikuti pertumbuhan Malthus. Sementara itu, model yang dibahas dalam artikel ini menggunakan asumsi pertumbuhan prey mengikuti pertumbuhan logistik agar lebih realistis. Selanjutnya, model diaplikasikan pada 
prey wereng batang coklat dengan predator kepik mirid dan kumbang tomcat. Simulasi dilakukan secara numerik dengan metode Runge-Kutta.

\section{MODEL PREDATOR-PREY DENGAN DUA PREDATOR}

Pada bagian ini akan dikaji tentang penurunan model predator-prey dengan dua predator. Variabel-variabel dan parameter yang akan digunakan untuk menurunkan model predator-prey dengan dua predator dituliskan dalam Tabel 1. Sementara itu, asumsi yang digunakan untuk menurunkan model tersebut adalah sebagai berikut:

1. populasi predator dan populasi prey bersifat tertutup, artinya tidak ada predator dan prey yang melakukan migrasi,

2. apabila tidak ada interaksi antara predator dan prey maka pertumbuhan prey mengikuti model logistik dan penurunan predator mengikuti model Malthus,

3. tidak terjadi interaksi antara predator yang satu dengan lainnya,

4. antara predator yang satu dengan lainnya tidak saling berkompetisi.

Tabel 1.Daftar variabel dan parameter yang digunakan

\begin{tabular}{|c|l|c|c|c|}
\hline Simbol & \multicolumn{1}{|c|}{ Definisi } & Jenis & Syarat & Satuan \\
\hline$N(t)$ & Jumlah prey pada saat $t$ & Variabel & $N(t) \geq 0$ & ekor \\
\hline$P(t)$ & Jumlah predator pertama pada saat $t$ & Variabel & $P(t) \geq 0$ & ekor \\
\hline$Q(t)$ & Jumlah predator kedua pada saat $t$ & Variabel & $Q(t) \geq 0$ & ekor \\
\hline$t$ & Waktu & Variabel & $t \geq 0$ & satuan waktu \\
\hline$r$ & Tingkat pertumbuhan intrinsik prey & Parameter & $0<r \leq 1$ & $\begin{array}{c}\text { per satuan } \\
\text { waktu }\end{array}$ \\
\hline$K$ & Daya dukung lingkungan & Parameter & $K>0$ & ekor \\
\hline$\alpha$ & $\begin{array}{l}\text { Tingkat interaksi predator pertama } \\
\text { terhadap prey }\end{array}$ & Parameter & $0<\alpha \leq 1$ & $\begin{array}{c}\text { per ekor satuan } \\
\text { waktu }\end{array}$ \\
\hline$\varphi$ & $\begin{array}{l}\text { Tingkat interaksi predator kedua } \\
\text { terhadap prey }\end{array}$ & Parameter & $0<\varphi \leq 1$ & $\begin{array}{c}\text { per ekor satuan } \\
\text { waktu }\end{array}$ \\
\hline$\beta$ & $\begin{array}{l}\text { Tingkat interaksi prey terhadap } \\
\text { predator pertama }\end{array}$ & Parameter & $0<\beta \leq 1$ & $\begin{array}{c}\text { per ekor satuan } \\
\text { waktu }\end{array}$ \\
\hline$\gamma$ & $\begin{array}{l}\text { Tingkat interaksi prey terhadap } \\
\text { predator kedua }\end{array}$ & Parameter & $0<\gamma \leq 1$ & $\begin{array}{c}\text { per ekor satuan } \\
\text { waktu }\end{array}$ \\
\hline$c$ & Tingkat kematian predator pertama & Parameter & $0<c \leq 1$ & $\begin{array}{c}\text { per satuan } \\
\text { waktu }\end{array}$ \\
\hline$e$ & Tingkat kematian predator kedua & Parameter & $0<e \leq 1$ & $\begin{array}{c}\text { per satuan } \\
\text { waktu }\end{array}$ \\
\hline
\end{tabular}


Berdasarkan asumsi, variabel, dan parameter yang telah disebutkan, diperoleh model predator-prey dengan dua predator, yaitu

$$
\begin{aligned}
\frac{d N}{d t} & =r N\left(1-\frac{N}{K}\right)-\alpha P N-\varphi Q N \\
\frac{d P}{d t} & =-c P+\beta N P \\
\frac{d Q}{d t} & =-e Q+\gamma N Q .
\end{aligned}
$$

\section{SOLUSI MODEL PREDATOR-PREY DENGAN DUA PREDATOR DI SEKITAR TITIK KESETIMBANGAN}

Model predator-prey dengan dua predator merupakan sebuah sistem persamaan diferensial non linier. Sistem tersebut dapat diselesaikan secara kualitatif, yaitu dengan cara melihat perilaku sistem di sekitar titik kesetimbangan. Dengan menggunakan metode nullcline, diperoleh titik kesetimbangan model predator-prey dengan dua predator, yaitu: $T E_{1}=(0,0,0), \quad T E_{2}=(K, 0,0)$,

$$
\begin{aligned}
& T E_{3}=\left(\frac{c}{\beta}, \frac{1}{\alpha}\left(r-\frac{r c}{\beta K}\right), 0\right), T E_{4}=\left(\frac{e}{\gamma}, 0, \frac{1}{\varphi}\left(r-\frac{r e}{\gamma K}\right)\right), \\
& T E_{5}=\left(\frac{c}{\beta}, \frac{1}{\alpha}\left(r-\frac{r c}{\beta K}-\varphi Q^{*}\right), Q^{*}\right), T E_{6}=\left(\frac{e}{\gamma}, \frac{1}{\alpha}\left(r-\frac{r e}{\gamma K}-\varphi Q^{*}\right), Q^{*}\right), \\
& T E_{7}=\left(\frac{c}{\beta}, P^{*}, \frac{1}{\varphi}\left(r-\frac{r c}{\beta K}-\alpha P^{*}\right)\right), \text { dan } T E_{8}=\left(\frac{e}{\gamma}, P^{*}, \frac{1}{\varphi}\left(r-\frac{r e}{\gamma K}-\alpha P^{*}\right)\right) . \text { Dalam }
\end{aligned}
$$

hal ini, $P^{*}$ dan $Q^{*}$ merupakan jumlah populasi predator pertama dan kedua pada keadaan setimbang. Menurut Korobeinikov dan Wake (1999), titik kesetimbangan model predator-prey dengan dua predator dibagi menjadi dua kasus, yaitu kasus umum dan kasus patologis. Titik kesetimbangan model predator-prey dengan dua predator pada kasus umum ada empat, yaitu: $T E_{1}=(0,0,0), T E_{2}=(K, 0,0)$, $T E_{3}=\left(\frac{c}{\beta}, \frac{1}{\alpha}\left(r-\frac{r c}{\beta K}\right), 0\right), \quad T E_{4}=\left(\frac{e}{\gamma}, 0, \frac{1}{\varphi}\left(r-\frac{r e}{\gamma K}\right)\right), \quad$ sedangkan titik kesetimbangan pada kasus patologis adalah $T E_{5}=\left(\frac{c}{\beta}, \frac{1}{\alpha}\left(r-\frac{r c}{\beta K}-\varphi Q^{*}\right), Q^{*}\right)$, 
$T E_{6}=\left(\frac{e}{\gamma}, \frac{1}{\alpha}\left(r-\frac{r e}{\gamma K}-\varphi Q^{*}\right), Q^{*}\right), T E_{7}=\left(\frac{c}{\beta}, P^{*}, \frac{1}{\varphi}\left(r-\frac{r c}{\beta K}-\alpha P^{*}\right)\right)$, dan

$T E_{8}=\left(\frac{e}{\gamma}, P^{*}, \frac{1}{\varphi}\left(r-\frac{r e}{\gamma K}-\alpha P^{*}\right)\right)$. Titik kesetimbangan model predator-prey dengan dua predator pada kasus umum terjadi di beberapa ekosistem, sedangkan untuk kasus patologis dapat terjadi pada interaksi antara dua virus penyakit yang menginfeksi satu inang. Pada penelitian ini hanya akan dibahas titik kesetimbangan model predator-prey dengan dua predator pada kasus umum.

Penyelesaian kualitatif sistem (1) dilakukan dengan cara melihat perilaku sistem di sekitar titik kesetimbangan. Berdasarkan analisis kestabilan titik kesetimbangan pada kasus umum, $T E_{3}=\left(\frac{c}{\beta}, \frac{1}{\alpha}\left(r-\frac{r c}{\beta K}\right), 0\right)$ akan bersifat stabil asimtotis jika $\frac{\gamma c}{\beta}<e$ dan $T E_{4}=\left(\frac{e}{\gamma}, 0, \frac{1}{\varphi}\left(r-\frac{r e}{\gamma K}\right)\right)$ akan bersifat stabil asimtotis jika $\frac{\gamma c}{\beta}>e$. Hal ini berakibat, tidak terjadinya keadaan koeksistensi (tumbuh secara beriringan) pada kedua predator dan untuk jangka waktu yang lama salah satu predator akan mengarah pada kepunahan lokal meskipun tidak ada kompetisi di antara keduanya.

\section{APLIKASI MODEL PREDATOR-PREY DENGAN DUA PREDATOR}

Model predator-prey dengan dua predator ini diaplikasikan pada ekosistem sawah dengan wereng batang coklat sebagai prey, sedangkan kepik mirid sebagai predator pertama dan kumbang tomcat sebagai predator kedua. Berikut merupakan nilai-nilai parameter dan nilai awal yang digunakan dalam simulasi model:

a. tingkat pertumbuhan intrinsik wereng batang coklat adalah 0,103 (Effendi, 2011),

b. daya dukung lingkungan (Carrying capacity), yaitu 600 ekor per rumpun (BPTP, 2010), 
c. tingkat interaksi predator pertama terhadap prey sebesar 0,136666667 (Laba, 2001),

d. tingkat interaksi prey terhadap predator pertama, yaitu 0,11 (Laba, 2001),

e. peluang kematian alami kepik mirid adalah $83 \%$ (Laba, 2001),

f. tingkat interaksi predator kedua terhadap prey sebesar 0,163333333 (Laba, 2001),

g. tingkat interaksi prey terhadap predator kedua, yaitu 0,06 (Laba, 2001),

h. peluang kematian alami kumbang tomcat adalah 51,90\% (Laba, 2001),

i. jumlah populasi awal wereng batang coklat adalah 30 ekor per rumpun,

j. jumlah populasi awal kepik mirid adalah 30 ekor per rumpun,

k. jumlah populasi awal kumbang tomcat adalah 30 ekor per rumpun.

Berdasarkan nilai-nilai parameter tersebut, diperoleh model predator-prey dengan dua predator untuk wereng batang coklat dengan predator kepik mirid dan kumbang tomcat, yaitu

$$
\begin{aligned}
\frac{d N}{d t} & =0,103 N\left(1-\frac{N}{600}\right)-0,136666667 P N-0,163333333 Q N \\
\frac{d P}{d t} & =-0,83 P+0,11 N P \\
\frac{d Q}{d t} & =-0,519 Q+0,06 N Q .
\end{aligned}
$$

Dengan demikian, berdasarkan definisi titik kesetimbangan maka diperoleh titik kesetimbangan $T E_{1}(0 ; 0 ; 0), T E_{2}(600 ; 0 ; 0), T E_{3}(7,545 ; 0,744 ; 0)$, dan $T E_{4}$ $(8,650 ; 0 ; 0,622)$ dari sistem (2). Pada kasus ini, simulasi model hanya dilakukan pada $T E_{3}$ dan $T E_{4}$. Berdasarkan analisis perilaku sistem (2) di sekitar $T E_{3}$ dan $T E_{4}$, diperoleh bahwa titik kesetimbangan $T E_{3}(7,545 ; 0,744 ; 0)$ bersifat stabil asimtotis dan $T E_{4}(8,650 ; 0 ; 0,622)$ bersifat tidak stabil.

Berdasarkan grafik hasil simulasi pada Gambar 1a dapat diketahui bahwa adanya kenaikan jumlah kedua predator menyebabkan penurunan jumlah wereng batang coklat yang drastis sampai batas tertentu; dan karena hanya terdapat satu jenis prey, yaitu wereng batang coklat yang jumlahnya terus menurun maka jumlah kedua predator tersebut juga turun menuju suatu nilai. Pada Gambar $1 \mathrm{~b}$ 
terlihat bahwa pada suatu waktu jumlah wereng batang coklat mengalami kenaikan yang cukup tinggi sehingga jumlah kepik mirid juga akan mengalami kenaikan hingga batas tertentu. Kenaikan jumlah kepik mirid ini mengakibatkan jumlah wereng batang coklat kembali mengalami penurunan. Adanya penurunan jumlah wereng batang coklat ini mengakibatkan jumlah kepik mirid kembali mengalami penurunan hingga batas tertentu. Keadaan ini akan terus berulang hingga jangka waktu yang lama sehingga jumlah populasi wereng batang coklat dan kepik mirid akan menuju ke suatu nilai tertentu, sedangkan populasi kumbang tomcat akan mengarah pada kepunahan lokal.

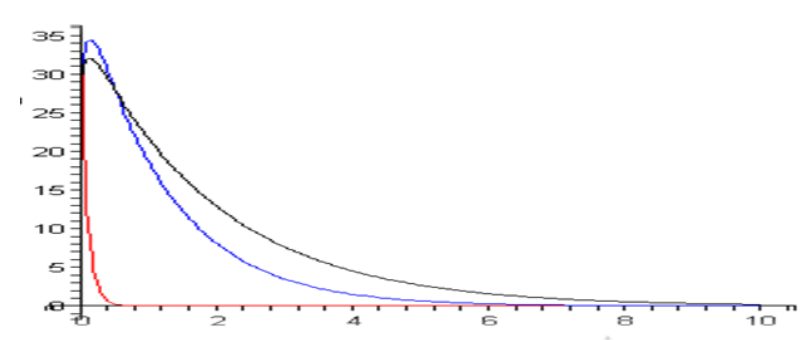

a. Perilaku wereng batang coklat dan kedua predator untuk waktu singkat

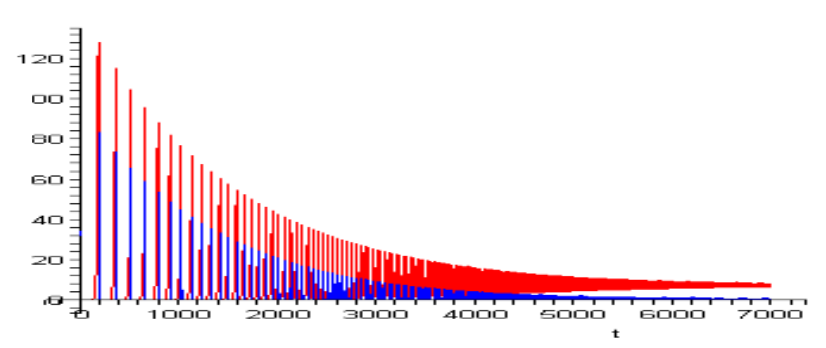

b. Perilaku wereng batang coklat dan kedua predator untuk jangka waktu lama

Gambar 1. Perilaku wereng batang coklat dan kedua predator pada sistem (2)

Keterangan Gambar 1:

: Grafik jumlah wereng batang coklat $(N)$ terhadap waktu $(t)$.
: Grafik jumlah kepik mirid $(P)$ terhadap waktu $(t)$.
: Grafik jumlah kumbang tomcat $(Q)$ terhadap waktu $(t)$.

Berdasarkan analisa kestabilan di sekitar titik kesetimbangan, $T E_{3}$ $(7,545 ; 0,744 ; 0)$ bersifat stabil asimtotis. Hal ini berarti, untuk jangka waktu yang lama jumlah wereng batang coklat akan menuju 8 ekor per rumpun, jumlah kepik 
mirid akan menuju 1 ekor per rumpun dan populasi kumbang tomcat akan mengarah pada kepunahan lokal.

\section{KESIMPULAN DAN SARAN}

\subsection{Kesimpulan}

Model predator-prey dengan dua predator yang menggunakan asumsi bahwa prey tumbuh secara logistik terlihat lebih realistis jika dibandingkan dengan asumsi pertumbuhan prey mengikuti model Malthus. Meskipun demikian, berdasarkan titik kesetimbangan yang diperoleh pada model dengan kedua asumsi tersebut, sistem pada kasus umum menunjukkan perilaku yang sama yaitu tidak terjadinya koeksistensi kedua predator. Dengan kata lain, salah satu predator akan mengalami kepunahan lokal untuk jangka waktu yang lama. Sementara itu, koeksistensi kedua predator hanya terjadi pada kasus patologis.

\subsection{Saran}

Penelitian lanjut dapat dilakukan pada model predator-prey dengan dua predator yang saling berkompetisi dan berinteraksi satu dengan lainnya.

\section{DAFTAR PUSTAKA}

BPTP Sulawesi Selatan. (2010) Antisipasi Serangan Hama Wereng Batang Coklat dan OPT lainnya.http://www.sulsel.litbang.deptan.go.id, diakses pada 17 September 2012.

Campbell, N. A. dan Reece, J. B.(2004) Biology Fifth Edition, Pearson Education, Inc., United State.

Edwards, C. H. dan Penney, D. E.(2008) Elementary Differential Equations Sixth Edition, Pearson Education, Inc., New Jersey.

Effendi, B. S.(2011). Strategi Fundamental Pengendalian Hama Wereng Batang Coklat dalam Pengamanan Produksi Padi Nasional, Pengembangan Inovasi Pertanian, 4(1), 63-75. 
Korobeinikov, A. dan Wake, G. C. (1999) Global Properties of The ThreeDimensional Predator-Prey Lotka-Volterra Systems, Journal of Applied Mathemathics and Decision Sciences, 3(2), 155-162.

Laba, I. W. (2001) Hama Utama Padi pada Ekosistem Sawah, Makalah Falsafah Sains, PPs 702. 